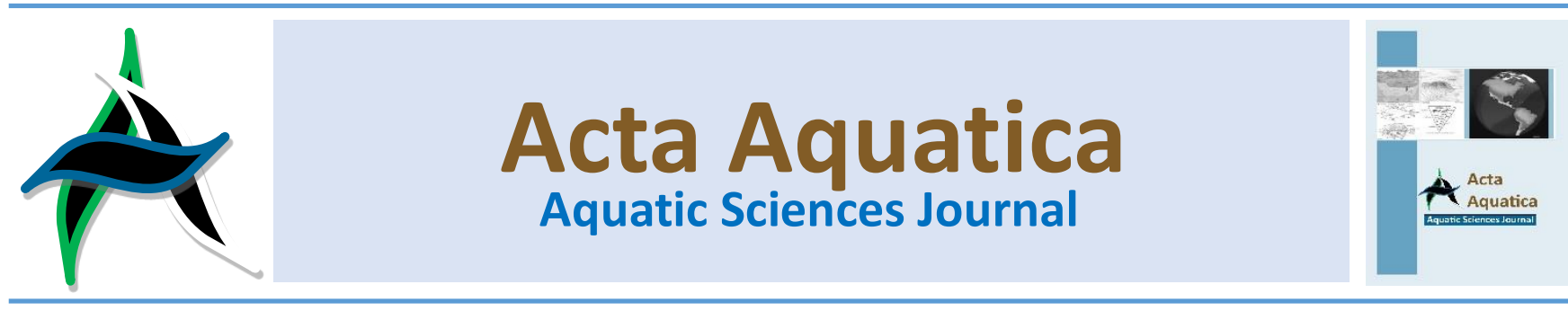

\title{
Pemanfaatan tepung cangkang kerang darah (Anadara granosa) sebagai sumber kalsium pada pakan ikan lele (Clarias batrachus sp)
}

\author{
The application of blood cockle (Anadara granosa) shell as calcium source for catfish (Clarias \\ batrachus sp) feed
}

\author{
Azizah Mahary ${ }^{\text {a }}$ \\ a Program Studi Budidaya Perairan, Fakultas Pertanian, Universitas Asahan
}

\begin{abstract}
Abstrak
Tepung kerang memiliki kandungan protein $2-3 \%$, dan kalsium $30-40 \%$, dengan besarnya persentasi kalsium yang dihasilkan dari tepung kerang tersebut maka diharapkan kebutuhan mineral yang dibutuhkan oleh ikan terpenuhi dan limbah yang dihasilkan pun dapat di kurangi. Penelitian ini bersifat eksperimental laboratoris menggunakan rangcangan percobaan Rancangan Acak lengkap (RAL) dengan 4 perlakuan dan 3 ulangan. Perlakuan yang diterapkan yaitu perbedaan konsentrasi penambahan tepung cangkang kerang darah $0 \%(\mathrm{P0})$ sebagai kontrol, 5\% (P1), dan $10 \%(P 2), 15 \%(P 3)$. Hasil penelitian menunjukkan tidak adanya perbedaan nyata pemberian tepung cangkang kerang darah pada pakan benih ikan lele dimana tingkat kelangsungan hidup yang tertinggi terdapat pada P2 (10\%) sebesar 58\%, pertambahan berat juga terdapat pada P2 sebesar 1,55 gr dan pertambahan panjang sebesar $1,82 \mathrm{~cm}$. Adanya pengaruh yang nyata terhadap pemberian pakan terdapat pada perlakuan $\mathrm{P} 3$ (15\%) sebesar $101.88 \%$ dimana $F_{\text {hit }}(4.88)>F_{\text {tab }}(5 \%)$ sebesar 3.86 dan (1\%) sebesar 6.99. Suhu dari awal hingga akhir penelitian berkisar antara $28-31{ }^{\circ} \mathrm{C}$, dan untuk $\mathrm{pH}$ memiliki nilai kisaran antara 6,38 sampai 3,91. Nilai DO pada P0 sebesar 3,0-3,2; P1 sebesar 3,2-3,5; P2 sebesar 3,5-3,6; dan P3 sebesar 2,0-3,1. Nilai nitrat berkisar antara 0-40 dimana nilai yang tertinggi terdapat pada P1 sebesar 10-40, sedangkan nilai nitrit pada tiap perlakuan memiliki nilai yang sama yaitu 0-0,25.
\end{abstract}

\begin{abstract}
The shellfish has protein $2-3 \%$ and calcium $30-40 \%$, with the large of calcium produced from the shellfish it is expected the required mineral of the fish need are met and the resulting waste can be reduced. The research was done experimental laboratory using a complete Randomized Design (RAL) experiment with 4 treatments and 3 replications. The treatment applied was the difference of concentration of flour shell starch $0 \%$ (P0) as control, 5\% (P1), and 10\% (P2), 15\% (P3). The result showed that there was no significant difference of flour shell meal on catfish seed feed where the highest survival rate was found in P2 (10\%) $58 \%$, weight gain was also found in P2 $1.55 \mathrm{gr}$ and $1 \%, 82 \mathrm{~cm}$. There was a significant effect on feeding in P3 treatment (15\%) of $101.88 \%$ where Fhit $(4.88)>\mathrm{Ftab}(5 \%)$ was 3.86 and (1\%) was 6.99. The temperature from beginning to end of the study ranges from $28-310 \mathrm{C}$, and for $\mathrm{pH}$ has a value range between 6.38 to 3.91 . The DO value at PO was 3.0-3.2; P1 of 3.2-3.5; P2 of 3.5-3.6; and $\mathrm{P} 3$ of 2.0-3.1. Nitrate value ranges from $0-40$ where the highest value is in $\mathrm{P} 1$ was $10-40$, while the nitrite value in each treatment has the same value that is $0-0.25$.
\end{abstract}

Keywords: catfish; fish feed; shells of blood cockle

\footnotetext{
* Korespondensi: Prodi Budidaya Perairan, Fakultas Pertanian, Universitas Asahan. Jalan Jend. Ahmad Yani, Kisaran Naga, Kisaran Timur, Kisaran, Sumatera Utara, Indonesia. 21216

Tel: +62-623-42643, Fax: +62-623-42643.

e-mail:azizah.maharyi@yahoo.com
}

\section{Pendahuluan}

Ikan lele merupakan salah satu komoditas unggulan disamping rumput laut, patin, bandeng, nila, dan kerapu yang akan dipacu pengembangan budidayanya dengan tujuan meningkatkan produksi budidaya pada beberapa tahun kedepan (Riyanto et al., 2010). Hal tersebut akan disertai dengan meningkatnya kebutuhan pakan pada budidaya ikan. Peningkatan kebutuhan pakan juga berlaku pada usaha pembenihan ikan. Pakan yang memenuhi kebutuhan gizi ikan 
dapat meningkatkan pertumbuhan benih ikan lele hingga mencapai ukuran benih siap jual. Namun pakan masih menjadi masalah pada beberapa pembudidaya ikan yang berada di sekitar kabupaten Batubara, khususnya pembenihan ikan lele.

Penerapan pemberian pakan buatan untuk budidaya ikan lele masih menjadi salah satu kendala dalam budidaya ikan lele. Tingginya harga pakan disebabkan oleh mahalnya bahan baku yang digunakan terutama tepung ikan. Oleh karena itu, perlu dicari alternatif bahan pakan dengan harga relatif murah, mudah didapat, dan mengandung nutrisi yang baik, untuk mengurangi penggunaan tepung ikan. Seperti halnya hewan lain, ikan pun membutuhkan gizi tertentu untuk kehidupannya, yaitu untuk menghasilkan tenaga, menggantikan sel-sel yang rusak dan untuk pertumbuhan. Zat gizi yang dibutuhkan adalah protein, lemak, karbohidrat, vitamin, mineral, dan air.

Pemanfaatan kerang darah merupakan usaha untuk memanfaatkan bahan baku lokal yang mudah didapatkan dan sering ditemui sebagai limbah bagi masyarakat. Kerang darah dapat diperoleh cukup banyak di Kabupaten Batubara dan sekitarnya. Alternatif penggunaan mineral untuk kebutuhan pakan ikan merupakan hal yang positif, karena jika tidak dimanfaatkan akan berdampak negatif terhadap lingkungan.

Menurut Setyaningrum (2009), kulit kerang merupakan bahan sumber mineral yang pada umumnya berasal dari hewan laut berupa kerang yang telah mengalami penggilingan dan mempunyai karbonat tinggi. Kandungan kalsium dalam cangkang kerang adalah 38\%. Tepung kerang memiliki kandungan protein $2-3 \%$, dan kalsium $30-40 \%$.

Kandungan yang terdapat dalam tepung cangkang kerang bukan hanya kalsium, tetapi juga protein dan fosfor yang dibutuhkan oleh hewan ternak untuk tumbuh, berkembang dan bereproduksi. Tepung kerang memiliki kandungan protein $2-3 \%$, dan kalsium $30-40 \%$. Tingginya kandungan kalsium yang dimiliki oleh tepung kerang darah tersebut melatar belakangi dilakukannya penelitian untuk mengetahui sejauh mana tingkat penggunaan tepung kerang darah dalam formulasi pakan terhadap efisiensi pemberian pakan dan laju pertumbuhan benih ikan lele.

\section{Bahan dan metode}

\subsection{Waktu dan tempat}

Penelitian ini dilaksanakan pada bulan AgustusSeptember 2017 yang bertepat di di Laboratorium Program Studi Budidaya Perairan, Fakultas Pertanian Universitas Asahan.

\subsection{Bahan dan alat}

Bahan-bahan yang digunakan adalah benih ikan lele, tepung ikan, tepung jagung, tepung kedelai, tepung cangkang kerang darah dan tepung kanji. Alat-alat yang digunakan dalam penelitian ini adalah kompor, dandang, saringan, mesin penggiling, baskom plastik, timbangan digital kantong plastik, lesung, penggaris, toples, $\mathrm{pH}$ meter, DO meter, botol plastik, dan wadah pemeliharaan ikan.

\subsection{Metode penelitian}

\subsubsection{Rancangan percobaan}

Metode yang digunakan adalah metode experimental laboratoris dengan pola Rancangan Acak Lengkap (RAL) dengan 4 (empat) perlakuan dan 3 (tiga) kali ulangan. Adapun perlakuan tersebut yaitu:
P1 : $\quad$ Pemberian pakan buatan dengan penambahan tepung cangkang kerang darah sebanyak $0 \%$ dari bobot total pakan.

P2: $\quad$ Pemberian pakan buatan dengan penambahan tepung cangkang kerang darah sebanyak $5 \%$ dari bobot total pakan.

P3 : Pemberian pakan buatan dengan penambahan tepung cangkang kerang darah sebanyak $10 \%$ dari bobot total pakan.

P4: Pemberian pakan buatan dengan penambahan tepung cangkang kerang darah sebanyak $15 \%$ dari bobot total pakan.

\subsubsection{Pembuatan tepung cangkang kerang}

Pembuatan tepung cangkang kerang darah berdasarkan modifikasi Nabil (2005) dimana Nabil mengaplikasikannya untuk pembuatan tepung cangkang srimping. Adapun cara pembuatannya adalah cangkang kerang darah di cuci bersih, di jemur dibawah sinar matahari hingga kering, cangkang kerang yang telah kering dihancurkan hingga berukuran $2-3 \mathrm{~cm}$, diesktraksi dengan $\mathrm{NaOH} 2 \mathrm{~N}$ dengan suhu $60^{\circ} \mathrm{C}$ selama 3 jam, selanjutnya pencucian kembali dengan air mengalir hingga $\mathrm{pH}$ netral, penepungan dengan mesin penggiling dan terakhir pengayakan

\subsubsection{Hasil uji proksimat}

Uji proksimat pakan benih ikan lele dengan penambahan tepung cangkang kerang darah dapat di lihat pada Tabel 1 .

Tabel 1.

Hasil uji proksimat pakan ikan lele dengan penambahan tepung cangkang kerang

\begin{tabular}{lcccc}
\hline $\begin{array}{c}\text { Komposisi } \\
\text { nutisi (\%) }\end{array}$ & P0 (0\%) & (P1) 5\% & P2 (10\%) & P3 (15\%) \\
\hline Air & 17,34 & 17,37 & 17,79 & 15,70 \\
Abu & 7,42 & 10,37 & 13,89 & 15,88 \\
Protein & 17,85 & 23,01 & 21,82 & 17,06 \\
Lemak & 11,56 & 10,94 & 10,45 & 9,33 \\
Serat kasar & 4,60 & 3,80 & 1,82 & 6,34 \\
Karbohidrat & 35,24 & 34,49 & 34,20 & 35,65 \\
Energi & 316,58 & 330,09 & 319,51 & 294,67 \\
& $k a l / 100 \mathrm{gr}$ & $\mathrm{kal} / 100 \mathrm{gr}$ & $\mathrm{kal} / 100 \mathrm{gr}$ & $\mathrm{kal} / 100 \mathrm{gr}$ \\
\hline
\end{tabular}

\subsection{Parameter pengamatan}

\subsubsection{Kelangsungan hidup}

Penghitungan kelangsungan hidup ikan menggunakan rumus menurut Goddard (1996) dalam Effendi et al. (2006) sebagai berikut:

$$
\mathrm{SR}=\frac{N t}{N 0} \times 100 \%
$$

Keterangan :

$\mathrm{SR} \quad=$ tingkat kelangsungan hidup (\%)

$\mathrm{Nt}=$ jumlah ikan hidup pada Akhir pemeliharaan ekor)

No = jumlah ikan pada awal pemeliharaan (ekor)

\subsubsection{Pertumbuhan panjang mutlak}

Pertumbuhan panjang mutlak dihitung menggunakan rumus Effendie (1979) dalam Effendi et al. (2006):

$$
\mathrm{Lm}=\mathrm{Lt}-\mathrm{LO}
$$


Keterangan:

LM = pertumbuhan Panjang Mutlak $(\mathrm{cm})$

Lt = panjang akhir $(\mathrm{cm})$

LO = panjang Awal

\subsubsection{Pertumbuhan bobot mutlak}

Penghitungan pertumbuhan bobot mutlak menggunakan rumus Weatherley 1972 dalam Dewantoro, (2001):

$$
W=W t-W 0
$$

Keterangan :

$\mathrm{W}=$ pertumbuhan bobot mutlak $(\mathrm{g})$

Wt = bobot ikan akhir pemeliharaan $(\mathrm{g})$

WO = bobot ikan awal pemeliharaan $(\mathrm{g})$

\subsubsection{Efisiensi pakan}

Penghitungan Efisiensi pakan dengan rumus Zonneveld et al. (1991) dalam Effendi et al. (2006) sebagai berikut:

$$
\mathrm{FE}=\frac{(W t+D)-W o}{F} \times 100 \%
$$

Keterangan :

$\mathrm{FE} \quad=$ efisiensi pakan (\%)

$\mathrm{Wt}=$ bobot ikan uji pada akhir penelitian (g)

Wo = bobot ikan uji pada awal penelitian (g)

D = bobot total ikan yang mati selama pemeliharaan (g)

$\mathrm{F} \quad=$ jumlah total pakan yang diberikan $(\mathrm{g})$

\subsubsection{Kualitas air}

Pengukuran parameter kualitas air meliputi suhu, $\mathrm{pH}, \mathrm{DO}$ dan amonia. Pengukuran suhu dan $\mathrm{pH}$ dilakukan setiap hari sedangkan DO dan amonia diukur pada awal dan akhir pemeliharaan.

\section{Hasil dan pembahasan}

\subsection{Kandungan nutrisi}

Pakan uji yang digunakan berupa pellet dengan penambahan tepung cangkang kerang darah dengan pencampuran tepung ikan, tepung jagung, kanji, dan tepung kedelai. Sebelum pakan diberikan pada benih ikan lele, terlebih dahulu dianalisis untuk melihat komposisi nutrisinya. Hasil analisa proksimat pakan uji dapat dilihat pada tabel 2 dibawah ini:

Tabel 2.

\begin{tabular}{|c|c|c|c|c|}
\hline $\begin{array}{l}\text { Komposisi } \\
\text { nutrisi (\%) }\end{array}$ & $\begin{array}{c}\text { Tepung } \\
\text { cangkang } \\
\text { kerang darah }\end{array}$ & $\begin{array}{c}\text { Tepung } \\
\text { ikan }\end{array}$ & $\begin{array}{l}\text { Tepung } \\
\text { kedelai }\end{array}$ & $\begin{array}{l}\text { Tepung } \\
\text { jagung }\end{array}$ \\
\hline Abu & 4,31 & 1,41 & 4,85 & 2,12 \\
\hline Lemak & 0,17 & 14,57 & 19,69 & 2,14 \\
\hline Protein & 0,15 & 7,44 & 38,26 & 5,51 \\
\hline Air & 1,66 & 11,42 & 6,59 & 10,14 \\
\hline Karbohidrat & 14,45 & 67,08 & 30,60 & 78,14 \\
\hline
\end{tabular}

Komposisi nutrisi beberapa jenis tepung untuk campuran pakan ikan

Hasil uji proksimat tepung cangkang kerang darah memiliki kadar kisaran protein, lemak, karbohidrat, dan abu yang cukup baik sehingga layak untuk digunakan sebagai bahan campuran untuk pakan ikan. Hasil pengujian pakan benih ikan lele yang telah ditambah cangkang kerang darah juga memiliki spesifikasi yang baik pada setiap perlakuan dimana kebutuhan nutrisi yang diperlukan oleh ikan telah terpenuhi. Menurut Mudjiman (2000), secara umum kebutuhan ikan akan protein berkisar antara 20-60\%, lemak 4-18\%, kadar abu maksimal 15\%, serat kasar tidak boleh dari $8 \%$ dan kadar karbohidrat berkisar antara $10-50 \%$.

Protein berperan penting untuk pertumbuhan karena mengandung asam amino esensial dan non-esensial. Protein merupakan sumber energy utama pada ikan, jika kebutuhan protein tidak dicukupi dalam makannya maka akan terjadi penururunan drastis atau penghentian pertumbuhan dan kehilangan bobot tubuh karena ikan akan menarik kembali protein dari beberapa jaringan untuk mempertahankan fungsi dari jaringan yang lebih vital.

Lemak adalah senyawa organik yang tidak larut dalam air, namun larut dalam pelarut organik sebagai sumber energi terpenting untuk pertumbuhan dan kelangsungan hidup ikan (Watanabe, 1988 dalam Rostika, 1997). Pakan yang baik umumnya mengandung 4 - 18\% lemak. Sedangkan menurut Suyanto (1994), kadar lemak yang optimal dalam menunjang pertumbuhan ikan adalah $2.57 \%$. Kadar lemak pakan uji berkisar antar 6,72\% - 10,07\%. , maka kandungan lemak pada pakan, dapat dikatakan kategori baik.

\subsection{Kelangsungan hidup (SR)}

Pengamatan benih ikan lele dilakukan selama 28 hari di dalam wadah berbentuk toples dengan volume 16 liter. Air yang digunakan adalah air tanah sebanyak 14 liter. Ikan yang dipelihara selama pengamatan berjumlah 12 ekor tiap wadah dengan 3 kali ulangan sehingga jumlah keseluruhannya adalah 36 ekor per perlakuan. Selama pemeliharaan benih ikan lele mengalami kematian yang ditandai dengan semakin berkurangnya jumlah ikan yang tersedia di dalam wadah (Tabel 3 dan Gambar 1).

Tabel 3.

Kelangsungan hidup ikan uji

\begin{tabular}{lcccc}
\hline Perlakuan & $\begin{array}{c}\text { Jumlah ikan } \\
\text { awal }\end{array}$ & $\begin{array}{c}\text { Ikan } \\
\text { mati }\end{array}$ & $\begin{array}{c}\text { Ikan } \\
\text { hidup }\end{array}$ & $\begin{array}{c}\text { Kelangsungan } \\
\text { hidup (\%) }\end{array}$ \\
\hline P0 (0\%) & 36 & 27 & 9 & 25 \\
P1 (5\%) & 36 & 21 & 15 & 42 \\
P2(10\%) & 36 & 15 & 21 & 58 \\
P3 (15\%) & 36 & 27 & 9 & 25 \\
\hline
\end{tabular}

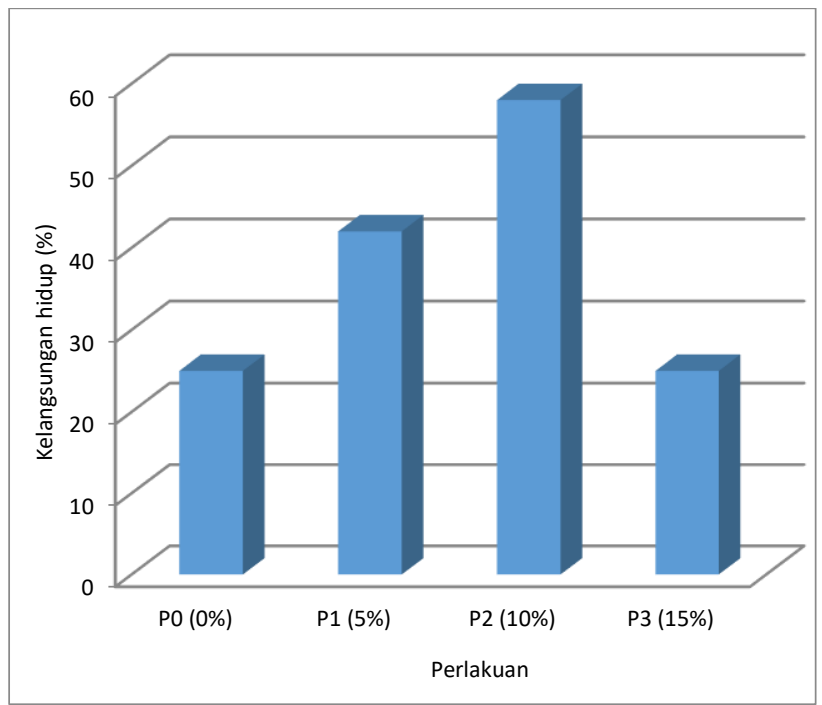

Gambar 1. Persentase kelangsungan hidup ikan uji. 
Kematian ikan lele di duga akibat stress dan adanya infeksi jamur serta bakteri. Adanya indikasi benih ikan lele terkena serangan virus dan jamur ditandai dengan mata menonjol, adanya bercak-bercak putih pada tubuh dan luka. Kondisi seperti ini juga terjadi pada penelitian Sopian (2013), dimana rendahnya nilai kelangsungan hidup ikan gabus disebabkan serangan penyakit dan dan sifat kanibalisme ikan gabus.

Tingkat kelangsungan hidup sangat ditentukan oleh pakan dan kondisi lingkungan sekitar. Menurut (Fahrur, 2013), pemberian pakan dengan kualitas dan kuantitas yang cukup serat, kondisi lingkungan yang baik, maka dapat menunjang kelangsungan hidup benih ikan lele.dimana ikan lele adalah salah satu ikan yang membutuhkan berkisar $35-40 \%$, lemak 9,5- 10 $\%$, karbohidrat $20-30 \%$, vitamin $0,25-0,40 \%$, dan mineral 1,0 $\%$, masing-masing untuk semua ukuran.

\subsection{Pertubuhan panjang dan berat benih benih ikan lele}

Pertumbuhan Panjang dan Berat benih ikan lele dilakukan per 7 hari sekali, untuk hasil pengamatan yang dilakukan dapat dilihat pada tabel 4 dan Gambar 2 dibawah ini.

Tabel 4.

Pertubuhan panjang dan berat benih benih ikan lele

\begin{tabular}{|c|c|c|c|c|c|c|}
\hline \multirow[t]{2}{*}{ Perlakuan } & \multicolumn{2}{|c|}{$\begin{array}{c}\text { Berat rerata } \\
\text { (gr) }\end{array}$} & \multirow{2}{*}{$\begin{array}{c}\text { Berat } \\
\text { mutlak } \\
\text { (gr) }\end{array}$} & \multicolumn{2}{|c|}{$\begin{array}{l}\text { Panjang rerata } \\
\text { (cm) }\end{array}$} & \multirow{2}{*}{$\begin{array}{c}\text { Panjang } \\
\text { mutlak } \\
(\mathrm{cm})\end{array}$} \\
\hline & Awal & Akhir & & Awal & Akhir & \\
\hline P0 & 3,06 & 4,34 & 1,28 & 6,37 & 7,73 & 1,36 \\
\hline P1 & 3,08 & 4,35 & 1,27 & 6,37 & 7,80 & 1,43 \\
\hline P2 & 3,07 & 4,62 & 1,55 & 6,39 & 8,21 & 1,82 \\
\hline P3 & 3,07 & 4,51 & 1,44 & 6,37 & 7,70 & 1,33 \\
\hline
\end{tabular}

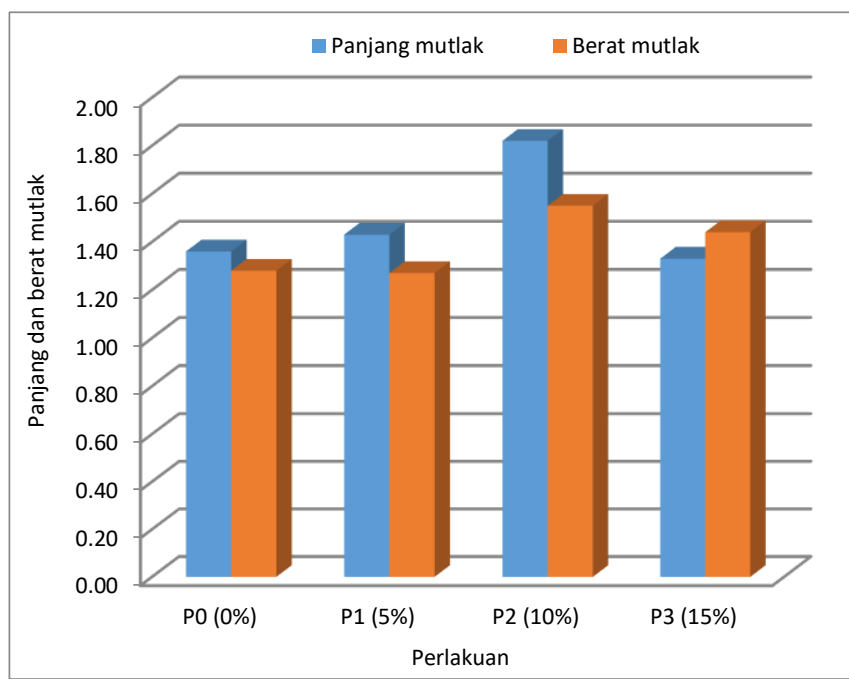

Gambar 1. Pertubuhan panjang dan berat benih benih ikan lele pada setiap perlakuan.

Hasil analisis sidik ragam menunjukkan bahwa $\mathrm{F}_{\text {hit }}(2,33)$ $<F_{\text {tabel }}(5 \%)$ 3,86 dan (1\%) 6,99 yang berarti penambahan tepung cangkang kerang darah tidak berpengaruh nyata terhadap pertumbuhan panjang dan $F_{\text {hit }}(1,45)<F_{\text {tabel }}(5 \%)$ 3,83dan (1\%) 7,00 terhadap berat benih ikan lele yang berarti tidah ada pengaruh terhadap penambahan tepung cangkang kerang darah.

Perbedaan pertrumbuhan tersebut disebabkan oleh kandungan nutrisi pakan yang diberikan pada benih ikan lele pada setiap perlakuan. Pakan merupakan kebutuhan utama dalam pertumbuhan benih ikan lele, selain makanan pertumbuhan benih ikan lele juga dapat dipengaruhi dengan perubahan suhu, kandungan oksigen, $\mathrm{pH}$, atau sifat air yang lain akan sangat mudah menyebabkan stres. Hal yang terpenting dalam pertumbuhan benih ikan lele adalah kebutuhan pakan dalam setiap harinya. Menurut Najiyanti (1992) menyatakan bahwa ikan lele sangkuriang membutuhkan makanan 3-5\% dari berat lele keseluruhan.

Kriteria kualitas pakan adalah kandungan proteinnya. Semakin tinggi kandungan proteinnya, kualitas pakan juga semakin bagus, akan tetapi nutrisi lain seperti karbohidrat juga dibutuhkan untuk pertumbuhan ikan lele. Pakan yang kandungan energinya atau karbohidratnya kurang akan menyebabkan ikan menggunakan sebagian protein sebagai sumber energi, sehingga bagian protein yang digunakan untuk pertumbuhan menjadi berkurang. Dengan kata lain jika benih ikan lele kekurangan karbohidrat maka akan menghambat pertumbuhan ikan lele tersebut.

\subsection{Efesiensi pakan}

Nilai efesiensi pakan benih ikan lele selama pengamatan dapat dilihat pada tabel 5 dibawah ini:

Tabel 5.

Efesiensi pakan ikan uji

\begin{tabular}{lc}
\hline Perlakuan & Nilai Efesiensi pakan (\%) \\
\hline P0 & $0.99^{\mathrm{d}}$ \\
P1 & $73.60^{\mathrm{b}}$ \\
P2 & $47.08^{\mathrm{c}}$ \\
P3 & $101.88^{\mathrm{a}}$ \\
\hline Keterangan: & Angka-angka yang diikuti oleh huruf kecil yang tidak sama pada \\
& kolom yang sama menunjukkan berbeda nyata menurut uji Beda \\
& Nyata Terkecil (BNT)
\end{tabular}

Dari tabel diatas dapat dilihat bahwa nilai efesiensi pakan ikan berkisar antara $0.99-101.88 \%$. hasil analisa anova nilai efesiensi pakan yaitu $F_{\text {hit }}(4.88)>F_{\text {tab }}(5 \%)$ sebesar 3.86 dan (1\%) sebesar 6.99 yang berarti bahwa ada pengaruh penambahan tepung cangkang kerang darah terhadap efesiensi pakan.

Hasil analisis sidik ragam menunjukkan bahwa pakan dengan penambahan tepung cangkang kerang darah berpengaruh nyata terhadap nilai efesiensi pakan benih ikan lele. Nilai efesiensi tertinggi diperoleh pada P3 (15\%) sebesar 101,88\% sedangkan nilai efesiensi terendah terdapat pada PO (0\%) sebesar 0,99\%. Menurut Kordi (2011), semakin tinggi nilai efesiensi pakan menunjukkan penggunaan pakan oleh ikan semakin efesien. Berdasarkan hasil penelitian yang dilakukan nilai efesiensi pakan dari semua perlakuan sebesar 0,99\% $101,88 \%$. Nilai efesiensi ini tergolong tinggi bila dibandingkan dengan ikan air tawar lainnya seperti nilai efesiensi pakan ikan nila hanya mencapai 50,23\% (Kurniasari, 2003 dalam Sugianto, 2007), nilai efesiensi ikan patin mencapai 73,1\% (Meilisca, 2003 dalam Sugianto, 2007), nilai efesiensi pakan ikan gurame mencapai 45,75\% (Suryani, 2001 dalam Sugainto, 2007).

Tingginya nilai efesiensi pakan pada penelitian ini diduga disebabkan oleh bahan pakan yang digunkan memiliki kecernaan yang tinggi. Menurut Djarijah (1995) menyatakan faktor yang menentukan tinggi rendahnya efesiensi pakan adalah jenis sumber nutrisi dan jumlah dari tiap-tiap komponen sumber nutrisi dalam pakan tersebut.

\subsection{Kualitas air}

Pengukuran parameter kualitas air yang diamati selama pngamatan dapat dilihat pada Tabel 6. Kisaran suhu dari awal hingga akhir penelitian berkisar antara $28-31^{\circ} \mathrm{C}$, dan untuk $\mathrm{pH}$ memiliki nilai kisaran antara 6,38 sampai 3,91 . Nilai DO pada $P 0$ sebesar 3,0-3,2; P1 sebesar 3,2-3,5; P2 sebesar 3,5-3,6; dan P3 sebesar 2,0-3,1. Nilai nitrat berkisar antara 0-40 dimana nilai 
yang tertinggi terdapat pada P1 sebesaar $10-40$, sedangkan nilai nitrit pada tiap perlakuan memiliki nilai yang sama yaitu 0-0,25.

Tabel 6.

Paremeter kualitas air media uji

\begin{tabular}{lccccc}
\hline & \multicolumn{5}{c}{ Parameter kualitas air } \\
\cline { 2 - 6 } Perlakuan & Suhu $\left({ }^{\circ} \mathrm{C}\right)$ & $\mathrm{pH}$ & $\begin{array}{c}\mathrm{DO} \\
\left(\mathrm{mg} \cdot \mathrm{L}^{-1}\right)\end{array}$ & $\begin{array}{c}\text { Nitrat } \\
\left(\mathrm{mg} . \mathrm{L}^{-1}\right)\end{array}$ & $\begin{array}{c}\text { Nitrit } \\
\left(\mathrm{mg} . \mathrm{L}^{-1}\right)\end{array}$ \\
\hline P0 & $28-31$ & $6-7$ & $3,0-3,2$ & $10-20$ & $0-0,25$ \\
P1 & $28-31$ & $6-7$ & $3,2-3,5$ & $10-40$ & $0-0,25$ \\
P2 & $28-31$ & $6-7$ & $3,5-3,6$ & $0-10$ & $0-0,25$ \\
P3 & $28-31$ & $6-7$ & $2,0-3,1$ & $0-10$ & $0-0,25$ \\
\hline
\end{tabular}

Nilai pH selama penelitian berkisar antara 6-7, sementara menurut Sunarma (2004) ikan Lele mempunyai toleransi bisa hidup di kisaran $\mathrm{pH} 6$ hingga $\mathrm{pH} 9$ yang berarti bahwa lele lebih toleran Basa dari pada Asam, namun kondisi ideal untuk kehidupan lele ada pada $\mathrm{pH} 7$ hingga $\mathrm{pH}$ 8. Nilai $\mathrm{pH} 6$ yang berarti bahwa $\mathrm{pH}$ air bersifat asam mengakibatkan benih ikan lele tidak memiliki pertumbuhan yang baik.

Kisaran suhu yang diukur pada awal dan akhir penelitian berkisar antara $28^{\circ} \mathrm{C}-31^{\circ} \mathrm{C}$. nilai suhu ini dapat dikatakan optimum untuk pertumbuahn benih ikan lele karena suhu yang ideal pada budidayaikan lele antara $28^{\circ} \mathrm{C}-31^{\circ} \mathrm{C}$. suhu $18^{\circ} \mathrm{C}-25^{\circ} \mathrm{C}$ ikan masih bertahan hidup tetapi nafsu makan mulai menurun. Suhu air $12^{\circ} \mathrm{C}-18^{\circ} \mathrm{C}$ mulai berbahaya bagi ikan, sedangkan suhu dibawah $12^{\circ} \mathrm{C}$ ikan lele akan mati kedinginan. Menurut Effendi (2006), suhu memegang peranan yang penting sebagai faktor lingkungan yang mempengaruhi pertumbuhan organism air tawar dan berhubungan erat dengan laju metabolism untuk pernafasan dan reproduksi.

Nilai oksigen terlarut (DO) selama pemeliharaan berkisar antara 2,0 - 3,6 (mg. $\left.\mathrm{L}^{-1}\right)$. Suhu yang terlalu tinggi atau terlalu rendah dapat menyebabkan pertumbuhan ikan tidak baik. Menurut Sunarma (2004), kisaran suhu yang ideal untuk pertumbuhan benih lele $22-34{ }^{\circ} \mathrm{C}$. Hal ini sesuai dengan SNI (2000), bahwa benih lele mampu hidup diperairan yang memiliki kandungan oksigen terlarut lebih besar dari $1 \mathrm{mg} / \mathrm{L}$. kelebihan pemberian pakan juga biasanya diikuti dengan proses pembusukan yang memanfaatkan oksigen terlarut dalam air kolam dan hasil akhirnya adalah bahan oragnik yang merupakan pupuk bagi fitoplankton.

Nilai nitrat yang tertinggi selama penelitian terdapat pada perlakuan $\mathrm{P} 1$ sebesar $10-40\left(\mathrm{mg}^{-1} \mathrm{~L}^{-1}\right)$ dan yang terendah pada P2 dan P3 sebesar 0-10 (mg. $\left.\mathrm{L}^{-1}\right)$. Siklus nitrogen tejadi dalam dua kondisi yaitu kondisi aerob dan kondisi anaerob. Pada kondisi aerob, selama nitrit terbentuk cepat, nitrit dioksidasi menjadi nitrat oleh bakteri nitrobacter. Pada kondisi anaerob, nitrat dapat berkurang menjadi nitrit yang selanjutnya hasil pengurangan tersebut dilepaskan sebagai gas nitrogen (Tuwo, 2011).

\section{Kesimpulan}

Hasil penelitian menunjukkan tidak adanya perbedaan nyata pemberian tepung cangkang kerang darah pada pakan benih ikan lele dimana tingkat kelangsungan hidup yang tertinggi terdapat pada P2 (10\%) sebesar 58\%, pertambahan berat juga terdapat pada P2 sebesar 1,55 gr dan pertambahan panjang sebesar $1,82 \mathrm{~cm}$. Adanya pengaruh yang nyata terhadap pemberian pakan terdapat pada perlakuan P3 (15\%) sebesar $101.88 \%$ dimana $\mathrm{F}_{\text {hit }}(4.88)>\mathrm{F}_{\mathrm{tab}}(5 \%)$ sebesar 3.86 dan (1\%) sebesar 6.99 .

\section{Bibliografi}

Djarijah, A.S., 1995. Pembenihan Ikan Mas. Kanisius. Yogyakarta.

Effendie, H., 2006. Telaah Kualitas Air. Kanisius. Yogyakarta.

Kordi, M.G.H., 2011. Kiat Sukses Budidaya Rumput Laut di laut dan Tambak. ANDI OFFSET. Yogyakarta. $134 \mathrm{Hal}$.

Mudjiman, A., 2000. Makanan Ikan (Edisi Revisi). Surabaya: Penebar Swadaya.

Najiyati, S., 1992. Memelihara Lele Dumbo di Kolam Taman. Penebar Swadaya. Jakarta.

Riyanto, S., W.I. Padang, Peni, 2010. Tabloid Agrina. Vol. 5, No.122.

Sugianto, D., 2007. Pengaruh tingkat pemberian maggot terhadap pertumbuhan dan efisiensi pemberian pakan benih ikan gurame (Osphronemus gouramy). Skripsi. Intitut Pertanian Bogor. Skripsi. Institut Pertanian Bogor.

Sunarma, A., 2004. Peningkatan Produktivitas Lele sangkuriang (Clarias sp.). Makalah disampaikan pada Temu Unit Pelaksan Teknis (UPT) dan Temu Usaha Direktorat Jendral Perikanan Budidaya, Departemen Kelautan dan Perikanan, Bandung 04-07 Oktober 2004. Bandung.

Tuwo, A., 2011. Pengelolaan Ekowisata Pesisir dan Laut. Brilian Interasianal. Surabaya. 